\title{
Provocative Dress and Sexual Responsibility
}

\section{JESSICA WOLFENDALE*}

INTRODUCTION . . . . . . . . . . . . . . . . . . . . . . . 599

I. What is Sexually Provocative Dress? . . . . . . . . . . . . . . 602

II. The Concept of Provochtion . . . . . . . . . . . . . . . . . . . 605

A. Elements of the Provocation Defense . . . . . . . . . . . . 606

B. From Objective to Subjective . . . . . . . . . . . . . . . . 607

C. The Victim's Behavior . . . . . . . . . . . . . . . . . . 608

D. Excuse or JustificAtion? . . . . . . . . . . . . . . . . . . 609

E. Three Models of Provochtion . . . . . . . . . . . . . . . 612

III. Provocation and Provocative Dress . . . . . . . . . . . . . . . . 613

A. The Moral Outrage Model . . . . . . . . . . . . . . . . 613

B. The Impaired Volition Model . . . . . . . . . . . . . . . . . 614

C. When is a Strong Emotion an Excusing Emotion? . . . . . 615

D. The Warranted Excuse Model . . . . . . . . . . . . . . . 617

E. The Privileging of Male Sexual Desire . . . . . . . . . . . . 618

IV. Responsibility and SeXual Provocation . . . . . . . . . . . 620

V. Conclusion ......................... 622

\section{INTRODUCTION}

In a 2012 survey prepared for the Vermont Governor's Prevention of Domestic and Sexual Violence Task Force, $46 \%$ of respondents believed that it was "sometimes true" that "[w]omen who wear tight or revealing clothing are inviting sexual comments or advances," and $60 \%$ of respondents aged eighteen to twenty-four agreed with the statement "[w]omen who wear tight or revealing clothing are inviting sexual comments or advances." One third of respondents in a 2005 Amnesty International survey of over 1,000 people in the United Kingdom believed that a woman who wore revealing clothing and behaved

\footnotetext{
* Associate Professor of Philosophy, West Virginia University. I would like to thank the editors of the Georgetown Journal of Gender and the Law for their valuable feedback on this article. I would also like to thank my colleagues in the Philosophy Department at West Virginia University; philosophers Jeanette Kennett, Rachana Kamtekar, Samantha Brennan, and Nancy Sherman; and law professors Kendra Huard Fershee, Atiba Ellis, Milton Regan, and Robin West for their helpful comments and suggestions that greatly improved this article. (C) 2016, Jessica Wolfendale.

1. Richard L. Clark \& Rebecca Casey, Castleton Polling Institute, Male Attitudes Regarding Domestic and Sexual Violence: Survey Data Report 12 (2012), http://www.vtnetwork.org/wpcontent/uploads/Male-Attitudes-Survey-FINAL-REPORT-Color2012.pdf.
} 
flirtatiously was partly responsible if she was raped. ${ }^{2}$ A study in Brazil found that $58.5 \%$ of those surveyed agreed with the statement, "[w]omen who wear tight-fitting clothes deserve it when they are attacked." 3 Over the last twenty years, other studies in the United States and elsewhere have found that psychiatrists, judges, jurors, and college students believe that a woman wearing a revealing outfit is more likely to be attacked or sexually harassed than a modestly dressed woman, and if attacked, that she is partially responsible for her assault, and her attacker is less culpable. ${ }^{4}$

These findings illustrate the persistence of the belief that a woman who wears tight-fitting and revealing clothing is inviting sexual attention. In discussions of these issues, such outfits are often described as "provocative," yet the appropriateness of that term remains unchallenged. In addition, it is rarely noted that it is only women's clothing that is described as sexually provocative. Men's clothing, no matter how revealing, is almost never described as provocative. ${ }^{5}$ In discussions concerning male victims of sexual assault, for example, whether the outfits worn by the victims at the time of the assault were revealing or tight-fitting is rarely, if ever, mentioned. There is no debate about whether reference to a male victim's clothing should be permitted in sexual assault cases because the question simply does not arise. ${ }^{6}$

2. UK: New Poll Finds a Third of People Believe Women who Flirt Partially Responsible for Being Raped, AMNESTY INT'L UK (Nov. 21, 2005, 12:00 AM), https://www.amnesty.org.uk/press-releases/uknew-poll-finds-third-people-believe-women-who-flirt-partially-responsible-being.

3. Astrid Prange \& Clarissa Neher, Brazilians Believe Victims Deserved Sexual Assault, Study Finds, DW (Apr. 4, 2014), http://www.dw.com/en/brazilians-believe-victims-deserved-sexual-assault-study-finds/ a-17536234.

4. See, e.g., Theresa M. Beiner, Sexy Dressing Revisited: Does Target Dress Play a Part in Sexual Harassment Cases?, 14 Duke J. Gender L. \& Pol'y 125, 152 (2007); Susan B. Kaiser, The Social Psychology of Clothing: Symbolic Appearances in ConteXt (Fairchild Publications 2d ed., rev. 1996) (1985); Chen Shen, Study: From Attribution and Thought-Process Theory to Rape-Shield Laws: The Meanings of Victim's Appearance in Rape Trials, 5 J.L. \& FAM. STUD. 435, 447-48 (2003); Donna Vali \& Nicholas D. Rizzo, Apparel as One Factor in Sex Crimes Against Young Females: Professional Opinions of U. S. Psychiatrists, 35 InT'L J. OfFEnder Therapy \& Comp. Criminology 167, 181 (1991).

5. Examples of the use of the term in academic work appear in the following articles: Beiner, supra note 4; Regan A. R. Gurung \& Carly J. Chrouser, Predicting Objectification: Do Provocative Clothing and Observer Characteristics Matter?, 57 Sex Roles 91, 97 (2007); and Vali \& Rizzo, supra note 4. These authors criticize references to women's clothing in rape and sexual assault cases, but do not question the appropriateness of "provocative" as an adjective. In relation to use of the term in the media and in other forums, an internet search with the term "provocative outfit" results in over a million and a half results, and a scroll through the first several hundred results reveals that the term is overwhelmingly used to describe women's outfits.

6. In the few studies on male sexual assault victims that exist, there is no reference to beliefs that male victims' clothing might have provoked the attack. A comparative study of rape myths about male and female rape victims found that rape myths regarding male victims included "men who are sexually assaulted by men must be gay," and "men cannot be forced to have sex against their will." These myths imply that male rape victims might be partly responsible for their assault because they either weren't "man enough" to fight back or didn't fight back because they were (perhaps secretly) homosexual. Rape myths regarding female victims, on the other hand, tended to attribute responsibility to the victims on the grounds that their behavior or dress showed that they "asked for it" or "wanted it." Thus, rape myths about victims of both sexes trivialize the harm of rape and attribute responsibility to the victims, but for 
In this article I challenge the assumption that it is appropriate to describe women's clothing as provocative and argue that continued use of this term normalizes and entrenches deeply problematic attitudes about women's responsibility for men's sexual behavior. These beliefs and attitudes not only affect women's everyday experiences but also have a profound impact on how the law treats the sexual assault and harassment of women. For example, in a 1986 sexual harassment case, the Supreme Court argued that a complainant's "sexually provocative" dress was "obviously" relevant to establishing whether "the alleged sexual advances were unwelcome." In another case, members of the jury that acquitted an accused rapist in a Florida trial told the media that "based on the victim's clothing, they believed she was a prostitute and therefore consented to the sexual acts." 8 Thus, there is a widespread belief that it is appropriate to describe revealing women's clothing as "provocative" and that women who wear such clothing could provoke sexual assault and harassment, despite no correlation between wearing revealing clothing and the likelihood of being sexually assaulted. $^{9}$

This article argues that the social interpretation of women's clothing as provocative arises from the objectification of women's bodies and the privileged social and legal status of men's sexual arousal. Women's clothing is taken to signify their sexual availability and desire for sex, independent from women's actual preferences..$^{10}$ I argue that describing women's clothing as provocative reinforces an objectified conception of women's bodies and sexuality that increases women's vulnerability to sexual assault and shapes social and legal attitudes about women's responsibility for such attacks.

Part I defines the meaning of "provocative" as applied to women's clothing and explores how men and women interpret the meaning of women's dress. While both men and women interpret revealing or tight-fitting women's clothing as indicative of a desire for sex, I demonstrate that this assumption is false, and that the theoretical assumptions about the relationship between women's outfits and men's sexual behavior are deeply flawed.

Part II explores the concept of provocation as a defense to murder in English Common Law ${ }^{11}$ and the U.S. Model Penal Code defense of extreme emotional

different reasons. Kristine M. Chapleau et al., Male Rape Myths: The Role of Gender, Violence, and Sexism, 23 J. InTERPERSONAL VIOLENCE 600, 601-605, 615 (2008).

7. Sharron J. Lennon et al., Forging Linkages between Dress and Law in the U.S., Part I: Rape and Sexual Harassment, 17 Clothing \& Textiles Res. J. 144, 156 (1999) (quoting Meritor Savings Bank v. Vinson, 477 U.S. 57, 68-69 (1986)).

8. Id. at 148 .

9. See A. Nicholas Groth with H. Jean Birnbaum, Men Who Rape: The Psychology of the OfFENDER 5-8 (1979); see also Avigail Moor, She Dresses to Attract, He Perceives Seduction: A Gender Gap in Attribution of Intent to Women's Revealing Style of Dress and its Relation to Blaming the Victims of Sexual Violence, 11 J. InT'L Women's Stud. 115, 125 (2010); Shen, supra note 4, at 441.

10. Moor, supra note 9.

11. See generally Jeremy Horder, Provocation and Responsibility (1992) for a discussion of the provocation defense. 
distress. $^{12}$ Examining the legal defense of provocation provides a useful framework for examining the meaning of provocative dress, since, while the legal defense of provocation is used only in murder cases, this defense involves many ideas that are implicit in the concept of provocative dress. In particular, the basis for the provocation defense is the belief that, in some cases, a person's wrongful actions can be partially excused or even partially justified because of another person's provoking behavior. After considering different models of the provocation defense, I conclude this section with a defense of the "warranted excuse" model proposed by Victoria Nourse, in which the defendant's wrongful behavior is partially excused "when the defendant appeals to the very emotions to which the state appeals to rationalize its own use of violence." 13

Part III applies these legal models of provocation to the concept of provocative dress to explore whether describing women's clothing as "provocative" implies that men's unwanted sexual behavior may be partially excused, partially justified, or warranted because of the nature of women's outfits. I argue that the "warranted excuse" model best captures the meaning of "provocative" when it describes women's clothing. In light of the meaning of provocative dress as explained in Part III, Part IV explores the relationship between responsibility and provocation. I critique the view that women bear at least some responsibility for men's sexual responses to their outfits, as well as the responsibility to ensure that their outfits are not "too provocative." Part V concludes the article by drawing on the work of philosophers Martha Nussbaum ${ }^{14}$ and Rae Langton ${ }^{15}$ to demonstrate how continued use of the term "provocative" reflects and reinforces the objectification of women's bodies, and undermines women's autonomy by attributing specific intent to women's outfits (despite what women themselves might say). The beliefs underpinning the idea of provocative dress thus not only shape and constrain women's everyday concerns about how their outfits and their bodies will be perceived and judged by others, but also affect the gravity with which the law and society view sexual assault, and how women's responsibility for sexual assault is assessed.

\section{What is Sexually Provocative Dress? ${ }^{16}$}

When a woman's outfit is described as sexually provocative, ${ }^{17}$ the description generally suggests that her clothing is revealing, tight-fitting, or viewed as

12. Model Penal Code $\S 210.3 \mathrm{cmt}$. (Am. Law Inst. 1980).

13. Victoria Nourse, Passion's Progress: Modern Law Reform and the Provocation Defense, 106 YALE L.J. 1331, 1338 (1997).

14. Martha C. Nussbaum, Objectification, 24 PHIL. \& PuB. AfF. 249, 291 (1995).

15. Rae Langton, Sexual Solipsism: Philosophical Essays on Pornography and Objectification (2009).

16. There are other ways of describing outfits as "provocative" that don't mean sexually provocative, which refer to both male and female clothing. For example, a person wearing a Nazi t-shirt to a synagogue would likely be described as provocative because we would assume that they are deliberately trying to provoke outrage or other similar feelings in those who see the t-shirt. Similarly, we might 
sexually suggestive in the context in which it is worn. ${ }^{18}$ According to one proposed definition, provocative dress "includes all female appearance styles that deviate from the acceptable norm of a specific social situation toward the direction of sexual suggestiveness and/or body exposure." ${ }^{\prime 9}$ According to this definition, wearing a bikini on a Florida beach is not provocative because a bikini is considered acceptable attire for the beach. However, wearing a bikini to a bar would count as provocative because in a bar, a bikini would be more suggestive of nudity or lingerie than of sunbathing or swimming at the beach. ${ }^{20}$

Several studies suggest that both men and women interpret certain kinds of women's clothing as indicative of a desire for sex. ${ }^{21}$ One study found that "both girls and boys reported that when a woman wore a see-through blouse, low-cut top, tight jeans, or did not wear a bra[,] she was possibly indicating a desire for sex." 22 In general, there appears to be agreement that "certain types of clothing are sexy, sexually alluring, or sexually provocative" ${ }^{23}$ — particularly clothing that reveals the shape of a woman's body and sexual body parts, such as her breasts. ${ }^{24}$ The classification of an outfit as "provocative" therefore involves a complex relationship between dress codes for specific contexts, cultural and social stereotypes of women's sexuality, and inferences about the wearer's intention.

However, in many of these studies, men were more confident than women in assigning sexual meanings to women's outfits: “men interpret women's verbal and nonverbal behaviors to be more sexually related than women intend." 25 In general, men routinely attribute sexual intent to certain kinds of women's clothing and behavior. ${ }^{26}$ Thus, a woman's outfit may be judged sexually

describe an outfit as "provocative" if it is worn to express criticism of (or support for) specific social, political, cultural, or religious practices, such as through the use of religious symbols or political slogans. The black gloves worn by Tommie Smith and John Carlos at the 1968 Summer Olympics to show their support of the Black Panther movement are a good example of this kind of provocative dress. See Daniel Yim, Wearing Your Values on Your Sleeve, in FASHION: PhILOSOPHY FOR Everyone 105, 105 (Jessica Wolfendale \& Jeanette Kennett eds., 2011) for a discussion of this example and the issue of clothing and political and social identity.

17. For the remainder of this article, I will use "provocative dress" to mean "sexually provocative dress".

18. Annette Lynch, Expanding the Definition of Provocative Dress: An Examination of Female Flashing Behavior on a College Campus, 25 Clothing \& TeXtiles Res. J. 185, 186 (2007).

19. Duncan Kennedy, Sexy Dressing Etc: Essays on the Power and Politics of Cultural IDENTITY 163-164 (1993).

20. A woman's race, age, and weight can also influence whether her outfit is perceived as sexually provocative. For example, given the highly sexualized images of African-American women in the media (such as in music videos), African-American women who wear body-revealing outfits are more likely to be viewed as "slutty." Duncan Kennedy, Sexual Abuse, Sexy Dressing and the Eroticization of Domination, 26 New Eng. L. Rev. 1309,1344 (1992).

21. Lennon et al., supra note 7; Lynch, supra note 18; Moor, supra note 9.

22. Lennon et al., supra note 7 , at 145.

23. Id.

24. Lynch, supra note 18, at 186.

25. Lennon et al., supra note 7, at 145 .

26. Lynch, supra note 18, at 186; Moor, supra note 9, at 116-17. 
provocative even if she had no intention or desire to provoke sexual attention. Simply put, if a woman is wearing an outfit that fits the definition of "provocative," observers-particularly men-are likely to attribute the intention to provoke sexual interest to her independently from her actual intentions. The problem with these assumptions is that a woman's decision to wear revealing clothing does not always mean that she is issuing a general invitation for sexual attention from men. In one study, only $3.2 \%$ of women surveyed stated that their intention in wearing revealing clothing was "to arouse men." "27 However, 30.6\% of men believed that women who wore revealing clothing "always intended to arouse men," and $53.2 \%$ believed that such women intended to arouse men "most of time." 28 This study indicates that women who wear revealing clothing are not necessarily intending to seduce men, and it highlights the gap between women's actual intentions in wearing revealing clothing and the intentions that men attribute to them.

Furthermore, in a society in which women's appearances are highly scrutinized, a woman might choose to wear sexualized clothing in different contexts for different reasons. For example, she might wear more revealing clothing to work because she believes that appearing attractive will assist her career. ${ }^{29}$ In addition, new fashions are often more revealing than fashions from previous decades, so a woman might choose revealing clothing out of a desire to appear cutting-edge. ${ }^{30}$ A woman might also choose a revealing or sexy outfit because she wants to fit in with a particular social group, or she might do so because she does want sexual attention. In many contexts, it is impossible for an observer to interpret a woman's sexual intentions from her outfit. ${ }^{31}$ Yet, describing revealing women's outfits as "provocative" assumes that there is an obvious connection between wearing revealing clothing and inviting sexual attention. This assumption was explicit in the 1986 U.S. Supreme Court sexual harassment case mentioned in the introduction, where the Court stated that a woman's work attire was "obviously relevant" to determining whether she sought sexual attention. ${ }^{32}$ The law, along with popular culture, "tends to focus on how others interpret the clothed individual, rather than on the interpretation and intent of the wearer."33

Additionally, in most contexts relating to clothing, "provocative" is synonymous with "sexy" or "revealing," but conflating these terms hides the fact that

27. Moor, supra note 9, at 120, 121.

28. Id.

29. Gabrielle Lofthouse, Press Release June 2010: Half Of Women Believe They Perform Better at Work When Dressed Sexily, HIRESCORES.COM, http://www.hirescores.com/press-release-article.php?id= 98 (last visited Apr. 7, 2016); Moor, supra note 9, at 118.

30. Lennon et al., supra note 7 , at 145.

31. There are some contexts where it would be reasonable for an observer to infer a desire for sexual attention from a woman's outfit, for example, if she was a prostitute in a known red-light district. Although, it is not clear whether the prostitute is signaling a desire for sex so much as a desire for business.

32. Lennon et al., supra note 7 , at 144 .

33. Id. at 146 . 
"sexy" men's clothing is rarely described as provocative. Indeed, unlike the case with women's outfits, it is not clear that there is a commonly held view about what constitutes a "sexy" man's outfit. But if provocative" is synonymous with "sexy" or "revealing," then both men's and women's outfits should be described by that term. So why isn't a sexily dressed man (however we define this idea) described as provocative? The answer lies in the relationship between provocation and moral responsibility.

\section{The Concept of Provocation}

To say a woman dresses provocatively does not simply mean that she dresses in order to be attractive to others. To describe a woman's outfit as provocative is to say that her outfit is likely to create certain sexual feelings in observers, and that those reacting to her outfit are not fully responsible for their behavior. The connection between provocation and responsibility may not be obvious when provocative is used as an adjective (as in "that's a provocative dress"), but it becomes apparent in statements such as "that dress provoked him." The latter statement implies two claims: that the dress incited strong emotions such as lust in the viewer, and that those emotions led him to engage in behavior in which he would not have otherwise engaged. Saying "that dress provoked him" implies that a man's subsequent wrongful behavior is partially excused or justified.

The claim of reduced responsibility, if understood as a moral excuse, suggests that a man aroused by a woman's outfit should be at least partially excused if his sexual arousal was so strong that he was unable to control his response. Alternatively, his behavior could be construed as partially justified if it was reasonable for him to infer from the woman's outfit that she desired sexual attention. ${ }^{34}$ This interpretation of the meaning of "provocative" as applied to women's outfits is consistent with the meaning of provocation at common law. In most Western countries, the partial defense of provocation is available to defendants who have committed acts of violence "in the heat of passion.." ${ }^{35}$ In a case of homicide, the provocation defense, if successful, reduces the charge from murder to voluntary manslaughter. ${ }^{36}$ While the provocation defense is used in the context of homicide cases rather than in sexual harassment or sexual assault cases in which the victim's clothing might be discussed at trial, elements of the

\footnotetext{
34. I will discuss the important differences between these interpretations in Part III, but for the moment it is sufficient to note that under either interpretation it follows that a man provoked by a woman's outfit should not be held fully responsible or blameworthy for expressing his sexual interest in her. By choosing to wear such an outfit, she must also bear some responsibility for his behavior.

35. Joshua Dressler, Rethinking Heat of Passion: A Defense in Search of a Rationale, 73 J. CRIM. L. \& CRIMINOLOGY 421, 422 (1982).

36. Uma Narayan \& Andrew von Hirsch, Three Conceptions of Provocation, 15 CRIM. Just. ETHICS $1-5,15$ (1996). For example, the California Penal Code defines voluntary manslaughter as "the unlawful killing of a human being without malice ... upon a sudden quarrel or heat of passion." CAL. PENAL CODE $\S 192$ (a) (West, 2015).
} 
provocation defense provide a useful framework through which to analyze the concept of provocative dress as it is used in the broader society.

\section{A. Elements of the Provocation Defense}

The provocation defense has its origins in English common law. ${ }^{37}$ In the common law tradition, to prove provocation, the defense must demonstrate the following: (1) that the defendant lost self-control in response to the victim's behavior (the subjective test); (2) that the defendant's actions followed immediately or very closely upon, and were caused by, that loss of self-control $;{ }^{38}$ and (3) that the victim's behavior would have caused a loss of self-control in any reasonable person (the objective test).$^{39}$ However, meeting the objective test typically does not require comparing the defendant's behavior with that of an ideally reasonable person, since such a person would presumably not lose self-control in the relevant circumstances. Instead, the relevant standard of 'reasonable' is traditionally interpreted as that of the ordinary person, with the ordinary person's capacity for self-control and no irrational or unusual character traits. ${ }^{40}$ As stated in a nineteenth century provocation case: "there must exist such an amount of provocation as would be excited by the circumstances in the mind of a reasonable man." ${ }^{41}$ Hence, to prove provocation, the defense needs to show that the defendant's loss of self-control was not the result of unusual character flaws, such as being "exceptionally belligerent." 42

The common law provocation defense has traditionally favored men accused of killing their spouses or sexual partners. ${ }^{43}$ The quintessential example of a provocation considered sufficient to reduce a charge of murder to one of manslaughter is that of a man catching his wife in adultery and killing her lover. ${ }^{44}$ Another traditional criterion of the provocation defense- that the defendant

37. Dressler, supra note 35 , at 422.

38. This requirement is necessary in order to distinguish crimes of passion from premeditated crimes. If the defendant attacked the victim after some time had passed, it is less plausible to suppose that the defendant's actions resulted from a loss of self-control.

39. Richard Holton \& Stephen Shute, Self-Control in the Modern Provocation Defence, 27 OXFORD J. Legal STUD. 49, 49 (2007). Other criteria include that the defendant's loss of self-control must be "sudden and temporary," and that the defendant's criminal behavior must be the immediate result of this loss of self-control. Id. at 50 (quoting R v. Duffy [1949] 1 All ER 932-33).

40. Christina Pei-Lin Chen, Provocation's Privileged Desire: The Provocation Doctrine, Homosexual Panic, and the Non-Violent Unwanted Sexual Advance Defense, 10 CoRnEll J.L. \& PuB. POL'y 195, 208 (2000).

41. Dressler, supra note 35, at 427 (quoting Regina v. Welsh [1869] 11 Cox Crim. C. 336, 338).

42. Dressler, supra note 35, at 428 (quoting Mancini v. D.P.P. [1941] 3 All ER 272, 277).

43. See Caroline Forrell, Gender Equality, Social Values and Provocation Law in the United States, Canada and Australia, 14 J. Gender, Soc. PoL'y \& L. 27, 71 (2006); Horder, supra note 11, at 186-98. See generally Danielle Tyson, Sex, Culpability and the Defence of Provocation 17-50 (2013).

44. Other categories of provocation considered sufficient to reduce a charge of murder to manslaughter by early English courts included a "grossly insulting assault," "seeing a friend, relative, or kinsmen attacked," and "seeing an Englishman unlawfully deprived of his liberty." HoRDER, supra note 11 , at 24 . 
acted out of "hot anger"- -also "favor[ed] something that men tend to do: act out of sexual jealousy." " ${ }^{45}$ The belief that the sight of a wife's adultery is provocation sufficient to reduce murder to manslaughter assumes that it is reasonable (or acceptable) that an ordinary, reasonable man confronted with his wife's adultery would respond with violence. As a result of this gendered interpretation of the provocation defense, for many years female victims of domestic violence who killed their partners were unable to use the provocation defense because such women typically did not kill in the "heat of anger" but rather, for example, while their victims were asleep. ${ }^{46}$

Partly in response to criticisms of the traditional provocation defense, the defense was reformed in the United States and in the United Kingdom during the 1950s and 1960s. The American Law Institute's Modal Penal Code ("MPC") included significant reforms to the provocation defense that have been adopted in whole or in part by eleven states and two territories. ${ }^{47}$ According to the MPC, manslaughter is defined as any intentional killing "committed under the influence of extreme mental or emotional disturbance for which there is reasonable explanation or excuse. The reasonableness of such explanation or excuse shall be determined from the viewpoint of a person in the actor's situation in the circumstances, as he believes them to be. ${ }^{48}$

There are two noteworthy differences between the MPC and common law versions of the provocation defense: (1) the shift from an objective standard of "reasonable" to a subjective standard and (2) the lack of reference as to whether the victim's provoking behavior was illegal or immoral.

\section{B. From Objective to Subjective}

By asking juries to place themselves in the defendant's shoes and adopt his perspective, the MPC significantly undermines the objective reasonable person standard of the common law provocation defense and gives juries wider discretion to decide what behaviors meet the adequate provocation standard. Under the traditional nineteenth century provocation doctrine, only four categories of behavior were considered sufficient provocation to reduce a charge of murder to manslaughter: "adultery, mutual combat, false arrest, and a violent assault." ${ }^{\prime 49}$ Only these four scenarios were held to enrage a reasonable man to the point of killing. However, the MPC's requirement that the jury consider the reasonableness of the defendant's actions from his point of view resulted in a broader range of cases reaching juries than would have occurred under the common law provocation defense, including departure cases in which the

45. Narayan \& von Hirsch, supra note 37, at 11.

46. HORDER, supra note 11, at 190; TYSON, supra note 43, at 24-30.

47. Nourse, supra note 13, at 1340 n.52.

48. Dressler, supra note 35, at 431 (citing Model Penal Code $\$ 210.3 \mathrm{cmt}$. at 43 (Am. Law Inst. 1980)).

49. Nourse, supra note 13 , at 1341. 
defendant killed his wife or girlfriend when she left or attempted to leave him. ${ }^{50}$ In her analysis of the application of the MPC's version of the partial defense, law professor Victoria Nourse found that "over one-quarter of the MPC claims (twenty-six percent [with a success rate of seventy-six percent]) that reached juries involved what I classify as a departure. ${ }^{, 51}$ In contrast, in jurisdictions using the common law provocation defense, "no departure claim in this category reached a jury."52 This suggests that the MPC reforms dramatically broadened the range of intimate partner killings in which it is considered reasonable to present juries with the option of returning a manslaughter charge on the basis of provocation or extreme emotional distress.

\section{The Victim's Behavior}

In the common law tradition, the four categories of sufficient provocation involved situations in which the victim's actions were judged to be not only provoking, but also immoral or illegal. A wife's adultery was considered sufficient provocation due to her legal status as her husband's property; adultery was viewed as one man "stealing" another man's property. In the words of a judge from an early eighteenth century case: "adultery is the highest invasion of property . . . if a thief comes to rob another, it is lawful to kill him.",53

In contrast, the MPC does not restrict the use of the defense to cases in which the victim's provoking behavior is unjust, immoral, or illegal. Thus, it is unsurprising that the defense has been used in cases where defendants have killed their partners or ex-partners in response to the victim's morally permissible and legally protected actions, such as leaving a relationship, rejecting a suitor, and seeking a restraining order. The vast majority of cases in which the MPC defense is used do not involve sexual infidelity. ${ }^{54}$ This suggests that decisions regarding whether to bring a homicide case to a jury and whether to instruct juries that they may find manslaughter on the basis of provocation are influenced by the implicit belief that men's jealousy and possessiveness of their partners and ex-partners, and men's use of violence against partners who leave or try to leave, is subjectively reasonable. As Nourse puts it, "Elsewhere reform has acknowledged, even encouraged, women's freedom to divorce or separate. Reform of the passion defense, however, has yielded precisely the opposite result, binding

50. For example, in states that adopted the MPC, juries have been instructed that they could return a manslaughter verdict on the basis of extreme emotional distress in the following cases: defendant murdered his wife after she obtained a temporary restraining order and filed for dissolution; defendant murdered his girlfriend, her infant daughter, and her half-sister and mother within ten days of learning that his girlfriend was leaving him; and defendant killed his wife (who had been a victim of domestic violence at the defendant's hands) two days after she consulted a lawyer about getting a divorce. Nourse, supra note 13 , at $1343,1354$.

51. Nourse defines departure as involving a range of situations "from divorce to rejection." Id. at 1353.

52. Id. at 1352 .

53. HoRDER, supra note 11, at 39 (quoting R. v. Mawgridge (1706) 85 Eng. Rep. 1107, 1115).

54. Nourse, supra note 13, at 1332. 
women to the emotional claims of husbands and boyfriends long ago divorced or rejected." ${ }^{55}$

\section{EXCUSE OR JUSTIFICATION?}

There is a great deal of confusion among legal scholars about whether the provocation defense should be interpreted as a partial excuse, a partial justification, or as some combination of the two. This distinction is important, since a partial excuse diminishes the defendant's culpability without reducing the criminality of the defendant's action, whereas a partial justification reduces the defendant's responsibility by reducing the criminality of the defendant's action. In the common law tradition, the provocation defense is typically interpreted as a partial justification, since provocation is only considered sufficient to reduce a charge from murder to manslaughter in cases where the provoker's behavior is judged to be unlawful. ${ }^{56}$ In a partial justification model, it is the victim's unjust actions that mitigate the defendant's blameworthiness, rather than the defendant's emotional state. ${ }^{57}$ As a result, the victim is viewed as partially deserving of her own fate or "asking for it." 58 But the justification is partial because, since the defendant's life is not threatened by the victim's provoking behavior, the defendant's retaliatory actions are disproportionate to the wrongfulness of the victim's actions. ${ }^{59}$ In a discussion of three conceptions of the provocation defense, philosophy professor Uma Narayan and criminology professor Andrew von Hirsch refer to the partial justification model of the provocation defense as the "moral outrage" model: the defendant's actions are partially justified if they constitute a form of retaliation expressing his justified anger at the victim's unjustifiable behavior. ${ }^{60}$ Thus, even if the victim's behavior causes the defendant to experience extreme emotional distress, it is the immorality of the victim's actions that partially justifies the defendant's response. ${ }^{61}$

In contrast, the wording of the MPC implies that the provocation defense is a partial excuse. The MPC requires the defense to prove that the defendant's actions were "committed under the influence of extreme mental or emotional disturbance for which there is reasonable explanation or excuse" where "reasonable" means "from the viewpoint of a person in the actor's situation." 62

A partial excuse reduces the defendant's responsibility by showing that, while the defendant's actions are still judged to be wrong, the defendant is less blameworthy due to mitigating factors, such as extreme emotional distress. On

55. Nourse, supra note 13, at 1334.

56. Dressler, supra note 35, at 439; see also HORDER, supra note 11, at 85-86.

57. Dressler, supra note 35 , at 458.

58. Id. at 439.

59. Id. at 456 .

60. Narayan \& von Hirsch, supra note 36 , at 15 . Horder also discusses this conception of the provocation defense. HORDER, supra note 11, at 85-86.

61. Narayan \& von Hirsch, supra note 36 , at 15.

62. Dressler, supra note 35, at 431. 
the other hand, under the partial justification interpretation, it is the victim's unjust actions that mitigate the defendant's blameworthiness. ${ }^{63}$ Thus, by classifying the provocation defense as a partial excuse rather than a partial justification, the MPC does not imply that the victim's behavior is wrong or that the victim "asked for it." Rather, the language of the MPC suggests that the killer is less blameworthy due to his or her emotional state.

According to law professor Joshua Dressler, the language used in provocation cases suggests three independent explanations for how extreme emotional disturbance reduces responsibility: (1) by making it impossible for the defendant to "premeditate or form the requisite intent to kill;",64 (2) by rendering the defendant's action "largely involuntary;" or (3) by demonstrating that the defendant's action did not arise from a "bad or corrupt heart, but from infirmity of passion to which even good men are subject." ${ }^{15}$ The MPC adopts a version of the third explanation by describing the defense as a "concession to human weakness" and by claiming that the homicide should be "attributable to the extraordinary nature of the situation ... [and not] to the depravity of the actor." ${ }^{, 66}$ All three of these explanations are versions of what Narayan and von Hirsch describe as the "impaired volition model" of provocation. ${ }^{67}$ In the impaired volition model, the provoked agent is excused because he is judged to be "in the grip of powerful emotions that diminish his capacity to conform to the law." 68

There are puzzling aspects to both the partial excuse and partial justification interpretations of the provocation defense. In the partial justification interpretation, the defendant's actions are characterized as disproportionate retaliation against the victim arising from justified moral outrage at the victim's behavior. This characterization suggests that retaliation through violence (even homicide) could, in theory, be fully justified if it were proportionate to the victim's wrongful actions. However, this runs counter to the law's rejection of personal retaliation as a legitimate response to wrongdoing: "the law properly expects the provoked agent to refrain from personal retaliation" particularly since there are numerous non-violent methods one could use in order to express one's moral outrage. ${ }^{69}$ The partial justification interpretation has also been criticized on the grounds that it implies that victims are at least partially to blame for their attacks since their behavior was unlawful or immoral ${ }^{70}$ - a concern particularly relevant to the frequent use of the defense in relation to homicides with female victims. ${ }^{71}$

63. Id. at 458 .

64. Id. at 442 .

65. Id. at 442 (quoting State v. Cook, 3 Ohio Dec. Reprint 142, 144 (C.P. Hamilton Cnty. 1859)).

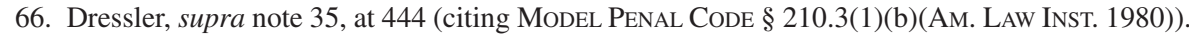

67. Narayan \& von Hirsh, supra note 36 , at 15.

68. Id. at 15 .

69. Id. at 15 .

70. Dressler, supra note 35 , at 458 .

71. See Tyson, supra note 43, at 19. 
However, the partial excuse interpretation may permit the provocation defense in cases where the victim exercises basic moral and legal freedoms (such as the freedom to refuse a suitor or leave a relationship), and thus significantly broadens the range of cases to which the defense can be applied. In addition, while the partial excuse interpretation focuses on the defendant's emotional state without making explicit reference to the defendant's specific emotions, in practice the defense has tended to protect only "particular reasons for emotional disturbance," i.e., emotional disturbance arising from men's jealousy, rage, and possessiveness towards women. ${ }^{72}$ As a result, the partial excuse interpretation of the provocation defense has been used to excuse actions that are the result of some emotions (such as anger or jealousy) but not others (such as the emotions experienced by victims of domestic violence). But it is not obvious why emotions such as greed or envy could not also partially excuse a crime, if such emotions were "subjectively reasonable" from the defendant's perspective. ${ }^{73}$

Furthermore, in the many cases in which the provocation defense has been used by a defendant accused of killing his departing wife or girlfriend, Nourse argues: "To embrace the defendant's emotional judgments in these latter circumstances [of a woman leaving her boyfriend or husband] not only allows the defendant to serve as judge and executioner, but also as legislator." ${ }^{, 74}$ Nourse's claim refers to the fact that the partial excuse model can excuse defendants for killing their victims when their victims are acting in ways that are protected by law. Thus, the defendant's judgment (for example, that his wife's decision to leave him is punishable by death) supersedes the law's judgments that a woman is permitted to leave her husband and that her decision to do so should be legally protected.

Nourse proposes a model of provocation based on the idea of "warranted excuse" to address her critique of the MPC's version of the partial defense. Under her proposal, a provoked killer can plead provocation in cases where his extreme emotional response reflects "an emotional judgment ... that is uncontroversially shared [by the community], indeed that the law recognizes,"75 i.e., a judgment that is warranted. A man who kills his departing wife thus cannot plead provocation, since the law's protections of her actions demonstrate that the law does not share his emotional judgment that her departure warrants the use of violence against her. In contrast, a woman who kills her rapist could plead provocation since "she is expressing outrage in ways that communicate an emotional judgment (about the wrongfulness of rape) that is uncontroversially shared" by the community and is expressed through the law. ${ }^{76}$ Thus, it is

72. Nourse, supra note 13, at 1368.

73. John Gardner, The Logic of Excuses and the Rationality of Emotions, 43 J. VAlue InQuiRY 315, 315 (2009).

74. Nourse, supra note 13 , at 1338 .

75. $I d$. at 1392 .

76. $I d$. 
reasonable to partially excuse the rape victim's actions because her emotions are shared by the wider community, but she is only partially excused because she "claimed a right to use violence" that was not hers to claim. ${ }^{77}$ Nourse's proposed version of the provocation defense is narrower than the MPC's, since in Nourse's view, it is not sufficient to show that the defendant's response to the victim was subjectively reasonable. In order for the defendant's actions to be partially excused, social and legal norms must clearly support the defendant's emotional response to the victim's actions. ${ }^{78}$

Nourse's proposal reconciles the insight from the partial excuse model of provocation that the defendant's emotional state plays an important role in mitigating his responsibility, with the insight from the justification model that a plea of provocation should refer to features of the victim's behavior. Unlike in the partial justification model, however, in Nourse's proposal, reference to the victim's behavior is not used to determine whether the defendant's act of violence was partially justified. Rather, reference to the victim's behavior is relevant to determine whether the defendant's emotional outrage is warranted and not just subjectively reasonable (as in the MPC).

The criticisms of the common law and MPC interpretations of the provocation defense are compelling, and they have led some jurisdictions to abolish the defense altogether ${ }^{79}$ But Nourse's proposal is a plausible suggestion for reform that retains the intuitive appeal of the provocation defense and addresses some of the most serious objections to the defense.

\section{E. Three Models of Provocation}

The models of provocation discussed above can be summarized as follows: (1) Moral outrage model-The defendant's actions are partially justified if his actions are a form of disproportionate retaliation (based on objectively justified moral outrage) against the victim's unlawful or unjust actions; (2) Impaired volition model-The defendant is partially excused if his actions arose from extreme emotional distress that impaired his ability to control his actions, and his distress is subjectively reasonable given his understanding of the situation; and

77. Id. at 1393 .

78. Narayan and von Hirsch also propose an alternative interpretation of the provocation defense that they term the "moral conflict" model. In the moral conflict model, the defendant is excused if his actions resulted from a conflict between the strength of his justified anger "at the victim and his conscience that 'discourages certain kinds of expressive behavior.'" Narayan \& von Hirsh, supra note 36, at 19. However, this approach "presupposes wrongdoing on the part of the victim," which raises difficult questions about whether this account avoids blaming victims. Id. at 20. In addition, Narayan and von Hirsch do not give an account of the criteria that would be used to establish whether and to what degree the victim's behavior was wrongful. Given these concerns with their view, Nourse's proposal is a more plausible option for reforming the provocation defense because she offers a method for determining under what conditions the defendant's outrage is warranted.

79. See Tyson, supra note 44, for a discussion of jurisdictions that have abolished the defense. Horder also argues in favor of abolishing the defense in light of entrenched gender bias that has plagued the use of the defense throughout its history. HORDER, supra note 11, at 186-98. 
(3) Warranted excuse model-The defendant is partially excused if his actions are based on an emotional judgment of the victim's actions that is shared by the community and expressed through the law.

All three models share some basic features: the defendant's emotional state must arise immediately or shortly after the victim's provoking behavior; the defendant's actions are judged against a standard of reasonable behavior (either objective or subjective); and the defendant's actions must result from his emotional state.

Even though the legal context of the provocation defense differs from the contexts in which "provocative" is used to describe women's clothing, and the provocation defense is legally applicable only to defendants accused of murder, these interpretations of the provocation legal defense provide a framework through which to analyze the idea of provocative dress. Each model provides a different way of explaining, first, how provoking behavior mitigates the responsibility of a person who is provoked to commit actions they otherwise would not commit and, second, whether provocative behavior partially excuses or partially justifies another person's bad behavior. Thus, these models offer different ways of thinking about what is implied in calling a woman's outfit "provocative." Below, I examine idea of provocative dress through the lens of all three models.

\section{PROvocation AND PROVOCATIVE DRESS}

\section{A. The Moral Outrage Model}

In the moral outrage model as applied to a defense for murder charges, the defendant's actions are partially justified if his actions are a form of disproportionate retaliation (based on objectively justified moral outrage) against the victim's unlawful or unjust actions. A first glance, this model does not seem to apply to the idea of provocative dress for two reasons. First, when a woman is described as dressing provocatively, this does not always imply that she acts immorally by wearing "provocative" clothing. Second, the emotion supposedly provoked by the outfit in question is not moral outrage but rather sexual arousal.$^{80}$ However, sometimes labeling a woman's outfit as "provocative" does imply both that it is sexually arousing and that it is immoral. This is most obvious in places where women are subject to severe legal punishment for wearing revealing clothing, such as in Iran. ${ }^{81}$ In Iran, one justification given for such punishment is that

80. However, revealing clothing could also be provocative in the sense of causing offense. In such cases, the moral outrage model might be appropriate if wearing such clothing is considered immoral in the relevant context. Wearing a bikini to a church would be provocative in this sense. However, this is not what is usually meant when a woman's outfit is described as provocative.

81. See Research Directorate, Iran: Enforcement of the Official Dress Code (2005 - Dec. 2007), IRN102671.E, IMMIGR. \& ReFUgEE BoARD CAN. (Jan. 10, 2008), http://www.irb-cisr.gc.ca/Eng/ResRec/ RirRdi/Pages/index.aspx $?$ doc $=451652$ \#archived. 
women who wear revealing clothing are both "un-Islamic" and a threat to "the security and decency of . . youth." 82 Thus, the judgment that an outfit is sexually arousing is accompanied by a punitive judgment that wearing such an outfit warrants legal punishment.

In Western liberal democracies, women are not legally punished for wearing revealing outfits. However, women are still subject to punitive responses as a result of the perceived provocative nature of their clothes. The studies cited in the introduction demonstrate the persistence of the widespread belief that a woman who was sexually assaulted is partially responsible for her attack if she wore a revealing outfit at the time of the attack. ${ }^{83}$ That the attack occurred and the victim suffered from the attack may be undisputed, but if she "asked for it" then her suffering is viewed as somehow warranted or fitting: it is an appropriate or deserved "punishment" for her choice to wear a provocative outfit. A woman wearing a revealing outfit is "asking for" unwanted sexual attention, so she cannot later complain if she received such attention. ${ }^{84}$

While women are not directly punished for wearing revealing clothing, the beliefs underlying phrases like "asking for it" are nonetheless highly punitive. The punitive nature of these beliefs becomes particularly evident when the outfit a woman was wearing at the time of her attack is used in rape and sexual assault trials as a reason to acquit or reduce the sentence of the defendant. ${ }^{85}$ However, since the idea of provocative dress does not always imply that a woman wearing revealing clothing is acting immorally or unlawfully, and does not generally imply that the feeling provoked in a man by a woman's outfit is moral outrage as opposed to arousal, the moral outrage model of provocation does not successfully capture the central meaning behind the concept of provocative dress.

\section{B. The Impaired Volition Model}

In the impaired volition model as applied to the legal context of a murder trial, the defendant is partially excused if his actions arose from extreme emotional

82. Id.

83. To recap, in the 2005 Amnesty International survey, one-third of respondents believed that a woman who wore revealing clothing and behaved flirtatiously was partly responsible if she was raped. The persistance of that belief is evident from the findings of studies over the last twenty years. These studies are discussed in Beiner, supra note 4; Kaiser, supra note 4; Shen, supra note 4; and Vali \& Rizzo, supra note 4.

84. Modern Family star Ariel Winters shut down her Instagram account after she was accused of "asking for it" when she posted a picture of herself in a bikini, with her two sons. Sean Fitz-Gerald, Modern Family Actress Ariel Winter Shuts Down Instagram-Shamers Who Wanted Her to Cover Up, N.Y. MAG.: The CuT (Nov. 16, 2015, 2:42 AM), http://nymag.com/thecut/2015/11/ariel-winter-instagramshamers.html.

85. After viewing photos of the victim's lace panties, bra (both with the Victoria's Secret label clearly visible), and short cocktail dress, the jury foreman in the 1991 rape trial of William Kennedy Smith commented that "she asked for it." Alinor C. Sterling, Undressing the Victim: The Intersection of Evidentiary and Semiotic Meanings of Women's Clothing in Rape Trials, 7 YALE J.L. \& FEMINISM 87, 89 (1995). I thank Rachana Kamtekhar for her helpful comments on this point. 
distress that impaired his ability to control his actions, and his distress was subjectively reasonable given his understanding of the situation. When applied to the concept of provocative dress, this model seems consistent with some everyday meanings expressed when women's outfits are described as "provocative." Under this interpretation, to describe a woman's outfit as provocative suggests that a man's unwanted behavior in response to a woman's clothing is excused because the strength of his sexual arousal impaired his ability to control his behavior and to realize that his behavior was unwanted by the woman in question. But how would sexual arousal undermine a man's ability to control his behavior? Sexual arousal can certainly be a strong sensation, yet it is far from obvious that it is strong enough to undermine an individual's capacity to reason and to control his or her actions. In everyday life, men interact with scantilydressed women in various contexts (on the beach, at a bar, on the street) without assaulting them. This suggests that the majority of men can control their sexual behavior even if they find a woman's outfit sexually arousing. ${ }^{86}$ But even if we grant the possibility that strong sexual arousal at the mere sight of a woman's outfit could lead a man to lose control over his actions, such a loss of control is insufficient to excuse his wrongful behavior.

\section{When is a Strong Emotion an Excusing Emotion?}

Under the MPC's provocation defense, extreme emotional disturbance reduces responsibility by undermining a person's capacity to form the requisite intent, by making that person's actions involuntary, or by showing that the person's actions did not arise from a "bad or corrupt heart." ${ }^{87}$ This version of the provocation defense is attractive because the belief that strong emotions can overwhelm a person's ability to control his or her behavior has intuitive appeal. But, equally intuitive is the belief that only certain emotions excuse wrongful behavior. As law professor John Gardner explains, emotional excuses function to excuse an agent's actions when "one claims to have been justified in one's emotions. The action is excused because the emotion in the thrall of which one acted is justified .... It was an unreasonable action in the grip of a reasonable emotion." ${ }^{88}$ Nourse, who shares a similar conception of excusing emotions, defends a partial excuse model of provocation based on a theory that delineates when and under what conditions a defendant's emotional response is warranted. ${ }^{89}$ Nourse argues that provocation is a partial excuse when the defendant's emotional response expresses a judgment

86. I recognize that there are important questions regarding the definition of self-control, and how and why emotions might overcome self-control. For the purposes of this article, however, such questions are outside the scope of this argument. For philosophical discussions of self-control, weakness of will, and emotions, see Alfred R. Mele, Backsliding: Understanding Weakness of Will (2012) and Jeanette Kennett, Agency and Responsibility: A Common-Sense Moral Psychology (2001).

87. Dressler, supra note 35, at 442 (quoting State v. Cook, 3 Ohio Dec. Reprint 142, 144 (C.P. Hamilton Cnty. 1859)).

88. Gardner, supra note 73, at 317.

89. Nourse, supra note 13, at 1338. 
about the victim's behavior that the community and the law share. ${ }^{90}$

Nourse's view that excusing emotions must be warranted or reasonable reveals further problems with the MPC's version of the provocation defense. In the MPC, the defendant's emotional distress excuses his wrongful action if his distress is subjectively reasonable, i.e., reasonable from "the viewpoint of a person in the actor's situation under the circumstances as he believes them to be." ${ }^{91}$ However, this view of excusing emotions suggests that, in theory, any emotion could be an excusing emotion if it is reasonable from the actor's point of view. For example, a man who robs a woman at knifepoint because he was overcome by intense greed would be able to plead provocation under this view ${ }^{92}$ if, due to his upbringing and beliefs, his belief that he was entitled to a share of her wealth was subjectively reasonable- a conclusion few would be willing to accept.

Given this discussion of excusing emotions, two conditions must be met in order for a man's overwhelming sexual desire to excuse his unwanted sexual advances toward a woman. First, his sexual desire must undermine his ability to control his actions. Second, his sexual desire must be a reasonable or warranted response to the woman's outfit. In other words, it would have to be shown that, because the woman wore a provocative outfit, it was reasonable for a male spectator to infer that she desired sexual attention. The following quote from a 2011 Daily Mail article about the sexual assault of CBS reporter Lara Logan illustrates this interpretation: "Nothing excuses the Cairo sexual assault on . . . Lara Logan, 39 . . but she does have 'form' for dressing provocatively in inappropriate locations." "93 The "but" in this sentence implies that, by "dressing provocatively," Logan invited sexual attention. As such, she should not complain when someone responds to her invitation.

Similarly, in 2011 a Canadian judge gave a convicted rapist a two-year conditional sentence instead of jail time on the grounds that the victim wore "suggestive attire" that "sent signals that "sex was in the air.",94 The rapist's guilt was mitigated, according to the judge, because it was reasonable for the rapist to believe that the victim wanted sex, given the way in which she was dressed. In both of these examples, the victims are held partially responsible for their sexual assaults because they wore clothing that, it is suggested, men would reasonably see as a sexual invitation. In each case the attacker's responsibility is lessened not

90. Id. at 1396 .

91. Model Penal Code $§ 210.3($ b)(Am. LaW Inst. 1980).

92. Gardner, supra note 73 , at 1 .

93. Ephraim Hardcastle, 'Toe-curling': Richard Mellor says Bahrain is a Friend of the West on Radio 4, DAILY MAIL (Feb. 17, 2011, 4:31 PM), http://www.dailymail.co.uk/debate/article-1358104/Toe-curlingRichard-Mellor-speaks-Bahrain-Radio-4.html.

94. Mike McIntyre, Rape Victim 'Inviting,'so No Jail: Judge Rules Woman's Clothes, Conduct Ease Blame on Attacker, WinNIPEG FrEe PrESS (Feb. 24, 2011, 1:00 AM), http://www.winnipegfreepress.com/ local/rape-victim-inviting-so-no-jail—rape-victim-inviting-so-no-jail-116801578.html. The "sex is was in the air" quote appears in Queen's Bench, Thompson, Manitoba, Transcript of Proceedings, $R$. $v$. Kenneth Rhodes, FEMINIST LEGal Forum 47 1. 20 (Feb. 18, 2011), https://feministlegalforum.files. wordpress.com/2011/11/rhodes-transcript-sentencing.pdf. 
because his self-control was undermined by sexual arousal, but because he was sexually aroused and his expression of sexual arousal is considered a reasonable response to the victim's outfit. Thus, because the impaired volition model only requires that sexual arousal undermine a man's self-control without making any reference to whether or not a man's sexual arousal is warranted, this model also does not adequately capture the beliefs implied by describing women's dress as "provocative."

\section{The Warranted Excuse Model}

The above discussion suggests that the moral outrage and impaired volition models of provocation fail to fully capture the meaning of provocative dress. Nourse's warranted excuse model, however, is closer to the way in which the idea of provocative dress is commonly used in the media, academia, and in other forums. When applied to a defense of murder, the warranted excuse model mitigates the defendant's responsibility if his actions are based on an emotional judgment of the victim's actions that is shared by the community and expressed through the law. However, in applying this model to the idea of provocative dress, the judgment that the community shares is not a judgment concerning the immorality of the victim's actions (as it is in standard provocation cases). Rather, it is a judgment about the victim's intentions and desires as expressed by her clothing. Applying this model to the idea of provocative dress leads to the following formulation: if a community shares the belief that a woman's sexually suggestive clothing is indicative of her desire for sexual attention, then it is reasonable for a man to infer that she is inviting sexual attention. As such, his unwanted sexual advances are partially excused because his judgment that she wanted sexual attention is warranted (i.e., shared by the community), but his actions are excessive or inappropriate expressions of that judgment (hence, they are only partially excused, not justified).

Note that this interpretation of the idea of provocative dress assumes that a woman who wears sexually suggestive clothing is inviting sexual attention from men, not just from a particular man (such as her boyfriend). Her choice of clothing is taken to express a generalized desire for sexual attention. This interpretation explains the belief that such a woman is not in a position to complain if she receives unwanted sexual advances, and that it is reasonable for any man to consider her outfit an invitation for sexual attention. As will become apparent in Part V, this aspect of the idea of provocative dress has important implications for the connection between the idea of provocative dress and objectification.

According to this understanding of provocative dress, it is warranted for ordinary men to interpret a woman's outfit as sexually inviting if her outfit is tight-fitting or revealing. But given the various reasons women might wear such clothing (as discussed in Part I), it is not clear that it is warranted for a man aroused by a woman's outfit to assume that she desires sexual attention from any man, let alone that she seeks sexual attention from him. A man is not morally 
blameworthy for being aroused by a woman's outfit, but the fact that he is aroused is not evidence that she intended to provoke that arousal or that his arousal is a reasonable response to her outfit. This point becomes obvious when we reverse the genders in the situation. Suppose a woman makes sexual advances toward a man because she is aroused by his outfit of tight shirt and jeans. He rebuffs her, but she continues her advances, claiming that he must want sex given what he is wearing. Can her behavior be excused? I suspect most people would not excuse her behavior because the man is wearing a sexy outfit, nor would they blame the man for her behavior. Men's outfits are not described as "provocative," and there is no social norm of attributing an intention to invite sex to men's choices of clothing. No matter how strong a woman's arousal, it would not excuse her harassment of him. On the other hand, as is clear from the examples offered in this article, men's sexual arousal has been often used to excuse sexual harassment and attacks on women, and women have been frequently held responsible for "inciting" such attacks.

\section{E. The Privileging of Male Sexual Desire}

The idea of provocative dress outlined above illustrates how social and legal norms privilege male sexual arousal. The social privileging of male sexual desire occurs when men's sexual desire is taken as a "given" that women must try to monitor and negotiate through their behavior and outfits. ${ }^{95}$ This point is aptly illustrated by events that occurred in Brooklyn in 2011, where, in the wake of several sexual assaults, police officers advised women not to wear shorts or skirts that were "too short." 96 This advice reveals how, in the eyes of the police, male sexual desire was considered an unchangeable and even dangerous aspect of the environment, and so it was up to women to change their behavior to try to protect themselves from sexual assault. However, men were not advised to modify their behavior to protect women. Instead, the permissibility of men's sexual behavior toward women remained entirely unquestioned.

The privileging of male sexual desire is also apparent in numerous school dress codes. These dress codes often target girls' outfits on the grounds that revealing or tight-fitting clothing might distract boys, ${ }^{97}$ but they do not penalize boys' outfits on the grounds that they might be sexually distracting to girls - a discrepancy that demonstrates how, unlike male desire, female sexual desire is not portrayed as a "given" that men and boys must be wary of and must avoid arousing. ${ }^{98}$ It reveals

95. I thank law professor Robin West for introducing me to this idea.

96. Katherine Bindley, NYPD to Women of Brooklyn's Park Slope: Don't Wear Shorts or Dresses, HuFFINGTON POST (Nov. 30, 2011, 5:12 AM), http://www.huffingtonpost.com/2011/09/30/nypd-to-womenof-south-park-dont-wear-shorts-or-dresses_n_989539.html.

97. Laura Bates, How School Dress Codes Shame Girls and Perpetuate Rape Culture, Time MaG. (May 22, 2015), http://time.com/3892965/everydaysexism-school-dress-codes-rape-culture/.

98. In fact, it is difficult to imagine what kind of boy's outfit would be considered sexually distracting to girls. This suggests that even very revealing men's outfits are not sexualized in the way that women's outfits are sexualized. 
how girls are held responsible for boys' sexual behavior, but not vice versa. Other examples of the social privileging of male desire include U.S. politicians suggesting the implementation of a dress code for interns in response to sexual harassment allegations, ${ }^{99}$ and commentators in a CNN discussion about the SlutWalk movement who stated, "You women that dress provocatively will attract the pervert/rapist whatever nearby. Simple as that. When they see boobs and thigh and butt they all go nuts. So don't entice them as much as possible."

Male sexual desire is also privileged in legal norms. First, as described in the section on the legal defense of provocation in Part II, it is privileged when male violence against women arising from sexual jealousy and sexual possessiveness is treated as "reasonable" or normal. The view that male violence against women who leave or reject them is a reasonable response to women's behavior privileges the view that it is "normal" for men to feel sexually possessive of women and to become enraged if women reject them or leave them. This view is then protected and reinforced through laws that permit male sexual jealousy and possessiveness to meet the criteria of the legal defense of provocation and thus mitigate the defendant's culpability.

Male sexual desire is also privileged in rape and sexual assault trials (and in media discussions of such trials) when victims are blamed for inciting male sexual desire through their outfits or behavior. ${ }^{101}$ This phenomena places the responsibility for controlling men's sexual behavior on to women. In contrast, men are not required to monitor their behavior and dress to avoid "tempting" women and inviting women's sexual advances. Female sexual desire is not portrayed as an unchangeable and potentially dangerous element of the environment that men must negotiate with in order to protect themselves from sexual assault and harassment.

99. Jason Hancock, Missouri Legislators Suggest an Intern Dress Code, but Speaker Nixes the Idea, KAN. CiTY STAR (Aug. 18, 2015, 7:49 AM), http://www.kansascity.com/news/local/news-columns-blogs/ the-buzz/article31374875.html. The dress code would have required interns to wear "good, modest, conservative dress" on the grounds that "[r]emoving one more distraction will help everyone keep their focus on legislative matters." Id.

100. Other statements made on CNN include, "Seriously if you wish to dress sexy and strut your stuff you should expect sexual violence. Yes you can blame the man who cannot control himself but if he is found guilty you should also be found guilty of being so inviting" and "Do not just blame the person doing the assaulting if you are going to run around strutting your stuff." Jessica Valenti, Why We Need SlutWalk: A Study in Comments, JESSICAVALENTI (2011), http://jessicavalenti.com/post/5451590186/whywe-need-slutwalk-a-study-in-comments. See also Kate Harding, Asking fOr IT: ThE Alarming RISE OF Rape Culture-And What We Can Do about It (2015) for many more such examples.

101. Shen, supra note 4, at 446. For example, in media coverage of the 2012 Steubenville trial of two teenage boys for the rape of a classmate several media outlets referred to the victim as "drunken." Annie-Rose Strasser \& Tara Culp-Ressler, How the Media Took Sides in the Steubenville Rape Case, ThinkProgress (Mar. 18, 2013, 9:15am), http://thinkprogress.org/health/2013/03/18/1732701/mediasteubenville/. A New York Times article on the gang rape of an 11-year old girl quoted residents of the area in which the girl lived as saying: "she dressed older than her age, wearing makeup and fashions more appropriate to a woman in her 20s.” James C. McKinlley, Jr., Vicious Assault Shakes Texas Town, N.Y. TIMES (March 8, 2011), http://www.nytimes.com/2011/03/09/us/09assault.html?_r=4. 
The privileging of male sexual desire in social and legal attitudes toward male and female sexual arousal and men's and women's responsibility for sexual behavior raises serious doubts about the appropriateness of the idea of provocative dress. The view that it is women's responsibility to ensure that their outfits do not incite or "tempt" men because male sexual desire is a potentially dangerous force is based on false inferences about the relationship between women's clothing and women's desires and intentions. It is true that many men and women interpret some kinds of women's outfits as evidence of a desire for sex, which suggests this view is widely held in the community. But this interpretation of women's clothing is based on the belief that there is a direct connection between the choice to wear revealing clothing and a desire for sexual attention from men (a belief that has been shown to be false) and the related false inference that if a woman's outfit arouses men, then she must have intended (or should have expected) her outfit to provoke that arousal. ${ }^{102}$

However, even if the idea of provocative dress is based on false beliefs about the relationship between women's clothing and women's intentions, and is sustained and reinforced by the social and legal privileging of male sexual desire, it is still important to ask whether women bear some responsibility for how men respond to their outfits. Since the belief that women who wear revealing clothing are expressing a desire for sex is widely held, and the attitudes toward male sexual desire described above are pervasive, at first glance this suggests that women do bear some responsibility for men's sexual responses to their outfits since women are likely to be aware that men often (wrongly) interpret certain outfits as sexually inviting. Accordingly, perhaps women are responsible for ensuring that they do not send the "wrong" message and invite unwanted sexual attention from men. This creates a dilemma for women: wear revealing clothing and risk unwanted sexual attention from men who assume that the outfit is a generalized invitation, or curtail clothing choices out of fear of sending the "wrong message."

\section{Responsibility and Sexual Provocation}

Blaming women for "sending the wrong message" is common-it is explicit in the Canadian judge's comments, ${ }^{103}$ in the CNN commentator's comments, ${ }^{104}$ and in the following remark from a Canadian police officer addressing students at Osgoode Hall Law School: "women should avoid dressing like sluts in order not

102. Moor, supra note 9.

103. The judge stated that the victim wore "suggestive attire" that "sent signals that "sex was in the air."” McIntyre, supra note 94.

104. "You women that dress provocatively will attract the pervert/rapist whatever nearby. Simple as that. When they see boobs and thigh and butt they all go nuts. So don't entice them as much as possible." Valenti, supra note 100. 
to be victimised." 105 The argument can be summarized as follows: if women know that men will view certain outfits as provocative, then it is foolish and even dangerous for them to wear such outfits and complain if they receive unwanted sexual advances. But this conclusion is too hasty. What exactly are women being blamed for in this argument? The above quotes imply that men are less blameworthy for their unwanted sexual behavior toward women because they understandably see some outfits as sexually inviting, so women may be blamed for objecting to sexual advances that they have implicitly invited. But if we deny that it is prima facie reasonable for men to infer a generalized sexual invitation from women's outfits and that men's sexual arousal can excuse inappropriate behavior, then the belief that men should be excused for acting on the assumption that scantily clad women are inviting sexual attention is much less plausible.

Even if it is unreasonable for men to assume that a scantily dressed woman is seeking sexual attention, perhaps women might still be criticized for being imprudent for wearing clothing that they know is likely to be interpreted as sexually inviting. This argument differs from that described above, in which men are viewed as less blameworthy because of their beliefs about women's sexual intentions. To blame a woman for being imprudent is to criticize her for not exercising sufficient self-protection, but that does not mitigate the responsibility or blameworthiness of men who sexually harass her. As an analogy, consider a case in which an African-American man talks to a white woman in the segregated South. In those circumstances, he might be violently attacked for speaking to her. Perhaps his behavior could be criticized on the grounds that he shows insufficient care for his own safety. But does that mean that if he is attacked, his attackers' actions should be excused? Does his imprudence diminish their moral responsibility? No. The question we should be asking is: Why was it dangerous for him to speak to a white woman in the first place? Talking to a white woman is not inherently dangerous. Doing so in the segregated South was dangerous only because of preexisting racist beliefs and practices that made an otherwise normal exercise of personal autonomy extremely risky. If the African-American man is attacked, the correct focus of blame and responsibility should be the men who attacked him and the social conditions that created the threat of attack.

Likewise, there is nothing inherently dangerous about wearing revealing clothing. In fact, there is nothing inherently sexual about such clothing ${ }^{106}$ or about women's bodies. For example, in some cultures, including some indigenous Australian cultures, women's breasts are not sexualized, and topless female

105. Ed Pilkington, SlutWalking Gets Rolling After Cop's Loose Talk About Provocative Clothing, GuARDIAN (May 6, 2011, 2:15 PM), http://www.guardian.co.uk/world/2011/may/06/slutwalkingpoliceman-talk-clothing.

106. Indeed, this is obvious if we think about revealing men's clothing. As I noted in Part I, while it is easy to picture a typical "sexy" women's outfit (short, revealing, tight-fitting), it is difficult to picture a typical "sexy" men's outfit. This suggests that clothing that reveals men's body shape, such as tight shorts or shirts, is not sexualized in the way that women's clothing is sexualized. 
attire is common. ${ }^{107}$ In Western culture, too, there are many contexts in which revealing and tight-fitting clothing — and even nudity — is not sexualized, such as during drawing classes with nude models, and at dance rehearsals, swimming classes, and the gym. When and if revealing clothing and women's body parts are sexualized depends on a complex set of factors including context as well as religious and social meanings. Thus, it is only potentially dangerous for women to wear revealing or tight-fitting outfits because of entrenched sexist beliefs and practices. These beliefs and practices include the idea that women who wear tight or revealing outfits want sexual attention, that women are "asking for it," that men are entitled to sexually approach women, and that women are responsible for men's sexual behavior. These preexisting practices unfairly influence women's decisions about what to wear with the fear of "sending the wrong message" and the threat of unwanted sexual attention.

Furthermore, controlling or predicting how others might interpret what one wears is difficult, if not impossible. As such, a woman's best attempts to "de-sexualize" her outfits may be unsuccessful. For example, it is quite possible - indeed likely - that Lara Logan, the reporter who was criticized for "dressing provocatively in inappropriate locations," 108 believed that her outfits were appropriate and not "too sexy." As a result, women's clothing choices are not only shaped by their personal values and identity, but also by the need to manage the social perception of the depersonalized female body as a collection of sexually charged features (breasts, hips, buttocks). A woman may see herself simultaneously as an individual whose actions express her subjective values and preferences and as a depersonalized object of male sexual attention. ${ }^{109}$ Since a woman cannot fully control a man's sexualized interpretation of her clothing, a woman's sense of ownership over her body and her clothing choices may be overshadowed and undermined by the threat of unwanted sexual attention.

\section{CONCLuSion}

The concept of provocative dress is based on the privileged status of male sexual arousal and the authoritative attribution of sexual intent to women's clothing regardless of women's stated desires. Notwithstanding their reasons for choosing certain outfits, women may be accused of provoking men's sexual desire and inviting men's sexual advances. Moreover, the idea of provocative

107. Aborigines' Fury Over Topless Ban, BBC News (Feb. 27, 2004, 4:02 PM), http://news.bbc.co.uk/ 2/hi/asia-pacific/3493408.stm.

108. Hardcastle, supra note 93.

109. Carolyn McLeod describes experiencing the effects of what she calls "partial objectification" when a crotch-level picture of her playing tennis was printed in the local newspaper and became a pin-up for men at the local garage. She was forced to see herself both as a successful tennis player and at the same time as "something that just gets men off." For McLeod, partial objectification can be malign when it occurs against a background of social inequality and when it denies the subjectivity of the object in ways in which they do not or could not consent to. Carolyn McLeod, Mere and Partial Means: The Full Range of the Objectification of Women, 32 CAN. J. PhiL. (SPecial Issue) 219, 220-23 (2002). 
dress normalizes the objectification of women's bodies. The analysis of objectification offered by philosophers Rae Langton and Martha Nussbaum in their work on objectification and pornography provides a helpful framework through which to examine this aspect of provocative dress. ${ }^{110}$

The concept of provocative dress reinforces two kinds of objectification. First, revealing women's clothing is construed as signifying sex by drawing men's attention to women's sexualized body parts; a woman's breasts, buttocks and legs can mean "sex" regardless of the personal desires of the woman in question. ${ }^{111}$ This is a form of "fungibility," a form of objectification discussed by Martha Nussbaum that involves the "reduction of a person to a set of body parts." 112 Second, and perhaps more troublesome, the idea of provocative dress illustrates what Rae Langton describes as the denial of autonomy through the affirmation of autonomy. ${ }^{113}$ When a woman's outfit is described as provocative, she is reduced to a depersonalized sexual object or collection of sexual body parts. In addition, a specific subjective desire is attributed to her-the desire for sexual attention from men. This attribution is not a form of respect for a woman's autonomy. Instead, it denies her autonomy by undermining the credibility and authority of her actual desires, even if she explicitly and repeatedly denies the attributed desire. Her stated preferences, if inconsistent with the intentions and desires that men attribute to her, are dismissed as not reflecting what she "really wants"—-she says "no," but her outfit says "yes." Thus, it is men's interpretations of her desires and intentions that are taken as authoritative. Women's actual spoken desires and intentions regarding men's sexual attention are silenced.

The authority given by social and legal norms to men's projected desires above women's stated preferences creates an additional concern for women regarding their clothing choices and behavior. Knowing that, despite one's intentions and clearly stated preferences regarding sexual attention from others, one could still be accused of "wanting it" or "asking for it" is highly disempowering; it means that a woman cannot control how her intentions and desires will be perceived, since her own desires and intentions are likely to be viewed as less reliable than those that are attributed to her by observers.

The concept of provocative dress is therefore far from a harmless description of women's clothing. Rather, this concept reflects and normalizes problematic beliefs about women's sexuality, women's bodies, and women's responsibility for men's sexual behavior. The beliefs underpinning the idea of provocative dress not only shape women's everyday experiences of their bodies and clothing choices but also shape how the law and society view the seriousness of sexual

110. Langton, supra note 15; Nussbaum, supra note 14.

111. Lynch, supra note 18, at 189.

112. Nussbaum, supra note 14 , at 264.

113. While Nussbaum includes denial of autonomy as form of objectification, $i d$. at 257, Langton argues that pornography denies women's autonomy by affirming the autonomy of the female participants by making it appear that they want to be treated in the manner they are treated. LANGTON, supra note 16. 
assault and harassment and women's perceived responsibility for these harms. Thus, the idea of provocative dress and the beliefs underlying it have a serious impact on women's everyday experiences of the risks of unwanted sexual attention. In order to challenge these beliefs and the harm they cause, we must reject language that trivializes the harm of sexual harassment and assault and that displaces responsibility for male sexual violence onto women. 